\title{
DESIGN THINKING AS A SOURCE OF MANAGEMENT INNOVATION
}

\author{
Grzegorz Baran*
}

\begin{abstract}
Background. The paper attempts to present design thinking as an approach which, when applied in management, can transform the mode of operation adopted in an organisation effectively enough to become in effect a source of radical changes and management innovation itself. Management innovation, though not so rare in management practice, has not become widespread in scientific literature, and is often wrongly identified with organisational innovation. It includes everything which significantly changes the manner of implementing management functions. It is very important to contemporary organisations, since by radically changing management methods, it is able to sustain an innovative potential in the long run.
\end{abstract}

Research aims. The aim of this paper is to identify these advantages of the design thinking approach which, when used in contemporary organisations, may be an efficient support in the creation and implementation of management innovation.

Methdology. The discussion undertaken in the paper is theoretical and primarily based on the method of the analysis and criticism of literature on design thinking and management, and management innovation in particular. The research method used to solve the scientific problem is deduction, which referred to the critical literature study has allowed achieving the research goal.

Key findings. The analysis of theoretical findings resulted in drawing how design thinking approach may effectively support the creation of management innovation in contemporary organizations. Although design thinking comes from a designers' job, at present it is an approach to creative and innovative ways of solving open, complex, and unambiguous management problems in numerous organisations.

Keywords: design thinking, innovation, management innovation, creativity.

* Wydział Zarządzania i Komunikacji Społecznej Uniwersytetu Jagiellońskiego, Kraków. E-mail: g.baran@uj.edu.pl 


\section{INTRODUCTION}

Although design thinking comes from a designers' job, at present it is an approach to creative and innovative ways of solving management problems in numerous organisations. Not only does it consider aesthetic or functional aspects, but in the holistic way, by concentrating on individual, subjective experiences and ways of understanding the world by the users, it leads to the creation of solutions attractive to them. In consequence, it introduces the humanistic dimension into management in a constructive way, and as an approach to design work it arises from the humanistic, explorative, and iterative attitude to reality. And as such, it seems to have a number of advantages which are attractive also from the point of view of creating management innovation.

The aim of the paper is to identify those advantages of the design thinking approach which, when used in contemporary organisations, may be an efficient support in the creation and implementation of management innovation. The deliberations undertaken in respect of the research problem defined in this way are theoretical and are primarily based on the method of the analysis and criticism of literature on design thinking and broadly understood management, and management innovation in particular. Deduction is the research method used to solve the scientific problem. The method referred to the critical literature study has allowed achieving the research goal. On the reasoning level, the analysis and synthesis methods were used to lead consequently to the identification of the aforementioned advantages supporting the processes of generating management innovation.

\section{DESIGN THINKING - THE ESSENCE AND THE SIGNIFICANCE FOR MANAGEMENT}

Design thinking is regarded by T. Brown a methodology which permeates the whole spectrum of innovative activities with the ethos of human-centred design (Brown, 2008, p. 86). The innovative attitude to the designed reality occurs as early as at the level of the way of defining it and will be manifested in each designed solution, or it will 
concern a new product, a new process, a new management method, or a new approach to management as such.

In spite of this distinctly marked usefulness for management and increasing popularity, particularly among practitioners, design thinking is a non-specific approach for management studies and still relatively poorly present in scientific literature. Moreover, there is still an ongoing discussion whether this is only a set of useful tools, a method of operation, or a completely new approach to solving problems, not only design ones any more, but any problems which require searching for innovative solutions (thus, also the ones on the grounds of management).

Taking the aforementioned arguments into consideration, the approach requires a deeper analysis and a broader description for the needs of the aim defined in the introduction. Due to its still poor recognisability on the grounds of management studies and the plurality of views, before the commencement of a detailed analysis of advantages which are significant from the point of view of management innovation, the readers should become acquainted with the essence of the approach, its origin and at least its basic properties. And this is the partial goal thus defined on which we will focus our attention, now.

The fact that the origin of design thinking is far from management is pointed out by numerous authors, among others by: E. Sanders and P. Stappers (2008), A. Dziadkiewicz and P. Maśloch (2013), D. Sobota and P. Szewczykowski (2014), L. Kimbell (2011), K. Dorst (2011), or M. Wszołek and M. Grech (2016). According to A. Dziadkiewicz and P. Maśloch, design, which is primarily associated with art and architecture, since the 1960s has been gradually entering the language of business and management, becoming a field related to the development of industry, science, engineering, and technology (Dziadkiewicz \& Maśloch, 2013, p. 93). To justify this thesis, the quoted authors on the one hand refer to the findings of the British Design Council, and on the other hand point to civilisation and generation changes which are difficult to follow with the traditional management methods.

Even a quite brief analysis of materials available at the British Design Council website indicates strong relationships between design and management, as well as successes coming from the combination of their assets in joint projects (British Design Council, electr. doc.). According to A. Dziadkiewicz and P. Maśloch, in order to manage better in the turbulent environment in which the process of changes is 
natural and people are more and more aware of growing opportunities, not only technological but primarily mental changes are necessary (Dziadkiewicz \& Maśloch, 2013, p. 93). The union of the powers of design and management enables not only better identification of new problems and opportunities, but also generation of highly innovative solutions.

L. Kimbell indicates the turn of the $20^{\text {th }}$ and $21^{\text {st }}$ centuries as the beginning of intense interest in design thinking, going beyond its traditional applications. The approach turned out to be particularly useful for innovation-oriented firms and in search for innovative solutions to social problems (Kimbell, 2011, p. 285). E. Sanders and P. Stappers emphasise that manufacturing enterprises are becoming more and more open to approaches which define product based on human needs (Sanders \& Stappers, 2008, p. 5). K. Dorst is of a similar opinion. According to him, in recent years design thinking has been gaining popularity as a new exciting paradigm of coping with problems in sectors which are so distant from each other as IT, business, education, and medicine (Dorst, 2011, p. 521).

M. Wszołek and M. Grech, in their commentary to the Polish edition of the book entitled Change by Design by T. Brown (2016), presented a thorough analysis of the theoretical bases of design thinking within the design methodology developing much longer. Among the sources of the studied approach, they identify, among others, human-centred design, participation design, Donald Norman's cognitive reflection or heuristic methods, some of which go back to the 1960s (Wszołek \& Grech, 2016, pp. 11-16).

The term design thinking itself is neither homogenous nor easy to define in an unambiguous way. As K. Dorst claims, there are a lot of reasons to be interested in this approach, and in consequence, a lot of ways of understanding and implementing it (Dorst, 2011, p. 522). U. Johansson-Sköldberg, J.Woodilla and M. Çetinkaya point out that design thinking begins to vary depending on the context in which it occurs. In the management sphere it is described explicitly as the best way to be creative and innovative, whereas in the design sphere it tends to be non-conscious as a natural component of the designing process, in spite of a long history of development and presence in the academic debate (Johansson-Sköldberg et al., 2013, p. 121). In this context, K. Dorst used the notion of collective awareness of designers (Dorst, 2011, p. 521). 
Thus, defining this approach as "thinking" seems to be appropriate as it is so deeply rooted in established operating methods that designers do not need to formulate it in the form of a method to use it efficiently in their everyday work. It is a natural part of their skills and tools. As M. Wszołek and M. Grech write, design thinking is a methodology of design work arising from a specific capital of attitudes towards design practice (Wszołek \& Grech, 2016, p. 13). Through a unique combination of divergent and convergent thinking on different levels of design work, each time we discover not only the final result but we rediscover the designing process. As T. Brown rightly observes, the designing process is a process of discovering within which a number of unexpected discoveries are made and therefore it is not possible to give it a linear structure within which structured activities would run (Brown, 2016, p. 48). However, he does not close his understanding of design thinking only in the narrow boundaries of a process or a simple, conventional method, on the contrary, he grasps it in broader frames of an approach to creative work (Brown, 2016).

This process of discovering, as D. Braha and Y. Reich emphasise, runs from some abstract specifications (as customer need or functional requirements towards the object being designed) and proceeds through subsequent approximations/improvements to a specific result (Braha $\&$ Reich, 2003, p. 186). The aforementioned focus on man materialises, among others, in empathic research into users' needs, whose results are synthesised in successive cycles in the form of prototypes of a gradually discovered solution. Design thinking as an exploratory and iterative process by its nature cannot be predictable as it does not lead to a predetermined result, but to a solution which we only discover in the process of studying the design structure with numerous opportunities and limitations.

Design thinking has also its simplified face for which representatives of other fields, including management, often reach. If we follow K. Dorsts who asks "What is the core of design thinking?" and "What could it bring to practicians and organisations from other fields?" (Dorst, 2011, p. 521), we will reach a conclusion that it is primarily a set of useful tools helpful in solving problems in an innovative way. Such authors include, among others, J. Liedtka and T. Ogilvie who, though they define design thinking quite broadly as a systematic approach to problem solving, pay special attention to a tool-related dimension. In their opinion, the starting point are customers and the 
ability to create a better future for them (Liedtka \& Ogilvie, 2011, p. 4). However, this ability is not a supernatural power, as it sometimes may generally seem when thinking about a designers' job, but a derivative of the skilful application of specific tools. Therefore, they postulate disenchanting design and translating it from an idea which is quite abstract to many people into a set of practical tools which also managers could use (Liedtka \& Ogilvie, 2011, p. 6).

Attempting here to synthesise the above deliberations, we can distinguish at least three ways of understanding design thinking: (1) as a set of tools, (2) a method or methodology of the implementation of the designing process, (3) an approach to problem solving. It is slightly differently presented by U. Johansson-Sköldberg, J. Woodilla, and M. Çetinkaya, who close the ongoing discourse around design thinking within five areas: (1) creating artefacts, (2) reflective practice, (3) problem solving, (4) a way of reasoning/making sense of objects, (5) creating meanings (Johansson-Sköldberg et al., 2013, p. 124). In the case of each one of them they point to strong scientific roots the discussion of which is not justified here considering the adopted aim of the paper.

However, there is an unquestionable fact that design thinking is a lot more than a set of tools taken from designers, useful in solving practical problems. It constitutes a strongly theoretically embedded, comprehensive approach, or maybe even a paradigm, as it is rightly proven by, among others, M. Wszołek and M. Grech (2016), which may considerably change the practice of acting and thinking about creation, also the creation of organisations and management methods. As it is proven every day in, among others, the IDEO company (which is attributed a substantial contribution in the popularisation of design thinking), this approach focused on man and his experiences is useful in the search for innovative solutions in almost each sphere of life: starting from the creation of new consumer goods, via education and health care, renewable energy sources, social problems, and ending with governmental programmes (IDEO, electr. doc.).

Let the above conclusion become the frame for the summary of the deliberations undertaken above, showing design thinking as a practical approach, but first of all as a solid theoretical base for new problems which we have to face today and in the case of which old ways of solving problems turn out to be insufficient. Therefore, more and more often, we search for interdisciplinary approaches, methods, and tools which 
can effectively overcome limitations of rigidly marked out disciplines. One of the areas where we encounter exactly such problems is management itself with regard to which there is an increasing conviction that it calls for fundamental, innovative changes. The next chapter will be devoted to this partial problem.

\section{MANAGEMENT - THE AGEING TECHNOLOGY}

The management innovation concept was presented by G. Hamel first in an article published in the Harvard Business Review (2006), and then in a book published together with B. Breen (2008). More or less at the same time, articles came out by J. Birkinshaw (2006) and M. Mol and J. Birkinshaw (2009) who co-worked with Hamel on this concept in the London Business School. According to them, surprisingly little attention has been devoted so far to the process of introducing innovation in management itself, G. Hamel does not hesitate to call management the ageing technology (Hamel \& Breen, 2008, pp. 18-23). Together with B. Breen he writes: "In the last century, we experienced radical changes in almost every area of life - from technology to geopolitics. In comparison with them, management practice seems to develop at a snail's pace. A president from the 1960s, suddenly resurrected and put at his old position, would be undoubtedly amazed at the flexibility of logistical chains and 24/7 technical service. However, when the first shock passed, he would easily manage the life of a corporation, as the majority of management rituals practically do not differ from those from before a generation or two" (Hamel \& Breen, 2008, p. 18; own translation).

G. Hamel emphasises that over the last century, breakthroughs like brand management or divisional organisational structure had been a source of much more permanent competitive advantage than whatever came out of laboratories or focus groups (Hamel, 2006, pp. 72-84). This view is also strengthened by the following words by J. Birkinshaw: "Many of the practices, processes and structures that we see in modern business organizations were developed during the last 150 years by the creative efforts of management innovators. Those innovators have included well-known names like Alfred P. Sloan and Frederick Taylor, as well as numerous other unheralded individuals and small groups of people who all sought to improve the internal 
workings of organizations by trying something new" (Birkinshaw, 2006, p. 81). Therefore, we are now facing the necessity to study the mechanisms governing management innovation. In further deliberations we will concentrate on the discovery and exploration of the essence of innovation of this type.

To understand better what management innovation is, it is worth attempting to reconstruct the term management itself on the most basic level. In 1917, H. Fayol defined management as the process of planning, organising, leading, coordinating, and controlling (Fayol, 1947). Although a century passed, the definition is still regarded valid by most of contemporary managers and it is in this form that the essence of management is passed to students, thus, replicated among next generations of managers. In a similar way management is defined, among others, by R. Griffin, the author of one of still fundamental coursebooks for young adepts of management. He also indicates the focus of these activities on the resources of an organisation to make it implement its objectives efficiently and effectively (Griffin, 2002, p. 38). As R. Maciag rightly observes "this old definition in spite of the lack of contemporary nuances, formulates the core and the basis" (Maciag, 2016, p. 11). The work has not been referred to here by accident, but because R. Maciag, polemically to management defined in this way, draws attention to a special role of man in management, writing, among others, that it is "the consideration of man which determines the humanism of management" (Maciag, 2016, p. 11). Not following this clue any more, as this is not the problem of humanism which is supposed to be resolved in this paper, I would like to point out that special consideration of man is one of these determinants which combine management and the title design thinking.

On the other hand, the adoption of industrial, effectiveness-based paradigm in management (which reduces man to the role of a worker or a consumer) is the reason for which one cannot deny the view of G. Hamel and B. Breen who called management "the ageing technology" (Hamel \& Breen, 2008, pp. 18-23). Even though managers try to face challenges posed to management by the $21^{\text {st }}$ century, the progress so far and the wish to introduce ground-breaking innovations into management is hindered by the effectiveness-based paradigm based on bureaucracy (Hamel \& Breen, 2008, p. 31). This is exactly the term paradigm that G. Hamel and B. Breen refer to in order to justify their standpoint, in their book The Future of Management (2008). They 
emphasise that "modern management is not only the set of useful tools and techniques. This is - due to the lack of a better term - a bit overused Thomas Kuhn's paradigm. According to the scholar, paradigm is more than the way of thinking - it is the whole vision of the world and the unshaken sense of which problems are worth solving and which are generally solvable" (Hamel \& Breen, 2008, p. 28). This vision may be so much embedded in the whole system built around given problems (research, education, practice) that some problems and promising solutions may be rejected a priori as not worth interest.

This is what happens in management where we still have a hierarchical system, even if it has been considerably flattened, and strategic decisions are taken by top managers the lower-rank staff are subordinated to, and who still perform the same tasks: they delegate tasks, establish budgets, assess performance, motivate their subordinates (Hamel \& Breen, 2008, p. 18). And all this to achieve higher effectiveness of the implemented activities. According to J. Poświata, even a simple change from a strife for effectiveness to a strife for efficiency can already change a lot (Poświata, 2017). Although a lot of managers believe that the notions are almost identical, the choice of one or the other operating philosophy is able to change substantially the attitude to strategy. In the case of effectiveness, we most often aim at the minimisation of outlays needed to accomplish specific goals. As a result, as J. Poświata writes, firms try to limit the amount of resources used (Poświata, 2017), which may lead to savings at the expense of limited investment. Focus on efficiency, namely the ratio of the value or the number of manufactured goods and services to outlays incurred, puts pressure on searching for solutions which will make people and organisations use the possessed resources better. And this is just one step to realise how important innovation is.

G. Hamel proves that management innovation (particularly in the area of basic principles or processes) may create long-term benefits and enhance competitive advantage to a much greater extent than it is possible in the case of other type of innovation (Hamel, 2006, pp. 72-84). According to Hamel, "a management innovation creates long-lasting advantage when it meets one or more of three conditions: The innovation is based on a novel principle that challenges management orthodoxy; it is systemic, encompassing a range of processes and methods; and it is part of an ongoing program of invention, where progress compounds over time" (Hamel, 2006, p. 73). 
G. Hamel defines management innovation as "a marked departure from traditional management principles, processes, and practices or a departure from customary organisational forms that significantly alters the way the work of management is performed" (Hamel, 2006, p. 75). Management innovations are understood in a similar way by M. Mol and J. Birkinshaw, for whom it is "the introduction of management practices that are new to the firm and intended to enhance firm performance" (Mol \& Birkinshaw, 2009, p. 1269). To understand the management innovation concept better, it is worth analysing the synthesis of contemporary management presented by G. Hamel. Among the activities included in management, we can distinguish the following (Hamel \& Breen, 2008, p. 36; Hamel, 2006, p. 76):

- $\quad$ "setting goals and laying out plans;

- motivating and aligning effort;

- coordinating and controlling activities;

- accumulating and allocating resources;

- acquiring and applying knowledge;

- building and nurturing relationships;

- identifying and developing talent;

- understanding and balancing the demands of outside constituencies".

According to G. Hamel and B. Breen, everything that distinctly changes the way of the implementation of the aforementioned activities, makes up management innovation (Hamel \& Breen, 2008, p. 36). According to J. Birkinshaw, "management innovation - that is the implementation of new management practices, processes and structures that represent a significant departure from current norms - has over time dramatically transformed the way many functions and activities work in organizations" (Birkinshaw, 2006, p. 81).

Management innovation is so important to contemporary organisations that only it is able to ensure a long-lasting innovative potential. It carries the capability of the continuous generation of subsequent innovation. It does not run out so fast as other innovations - technological, organisational or process ones, as it may constitute the source of subsequent changes. In a way, it is expressed by G Hamel on his website where he writes: "In our highly dynamic world, it's not enough for an organization to possess a competitive advantage at a point in time; it needs an evolutionary advantage over time - a capacity to change as fast as change itself; to change before a crisis breaks" (Hamel, electr. doc.). 
G. Hamel with his collaborators from the London Business School, conduct research into the history of management innovation and they give the following, among others, as an example of such innovation: knowledge-based management, new tools of rational capital allocation, intangible asset management, methods and tools for the use of talents and ideas of every employee, or building the Visa global virtual consortium (Hamel \& Breen, 2008, pp. 38-41). They also draw attention to the fact that inspiration for changes in management can be sought much earlier. They point out, among others, to the successes of Napoleon whose campaigns are still a training material in military academies all over the world because of changes in the military doctrine which today could be defined as management innovation. Therefore, management innovation is by no means such a rare practice although the term itself has not rooted in scientific literature strongly enough, and more often attention is paid to the significance of operational, product, or organisational innovation.

\section{FROM DESIGN THINKING TO MANAGEMENT INNOVATION}

Management innovation, as it was proven in the previous chapter, is so important to contemporary organisations because it ensures a relatively permanent competitive advantage. However, it is not a frequent practice in organisations. Firstly, because it requires new, unconventional activity going beyond the effectiveness paradigm prevailing in management. Secondly, it is difficult to change management radically only with the methods of management itself, as it is encumbered by deeply rooted thinking and acting patterns. Thus, it seems appropriate to look for inspiration for changes outside management. Therefore, the crucial task which is important to solve the partial problem posed in this way is to reveal those properties of the design thinking approach, which applied in organisations may be useful in the processes of searching for and implementing management innovation. In the next chapter we will focus on the synthetic presentation of the findings of this part of the research.

The results of the analysis of the design thinking approach have enabled isolating the aforementioned properties. When synthesising the findings obtained before, the following advantages are identified, 
which seem particularly attractive from the point of view of management innovation:

- creating human-centred solutions;

- the process of discovering and the method of creative activity;

- unconventional thinking and creating conditions for creative pushing the limits;

- creativity and innovativeness;

- unleashing cooperation by inspiring the formation of interdisciplinary teams;

- holistic approach to solution creation;

- $\quad$ systematic embedding in a business model.

One of the key advantages of design thinking is the non-reducible orientation of the approach to man and his experience, which is a strong link to the contemporary thought about management, in which it is the humanistic dimension that is more and more strongly present. It is non-reducible mostly in the sense that without man this approach is simply unthinkable. It is not about ethical or axiological saturation of the process with humanistic values but the point is that design thinking is a process of discovering a solution which would be the best for an individual in the constant relation to the experience of this individual. Therefore, as T. Brown writes, "it is not only human-centred; it is deeply human in and of itself" (Brown, 2016, p. 37).

It is clearly the common point with the humanistic stream in management which J. Kociatkiewicz and M. Kostera rightly define as "the internally coherent research programme aimed at the recognition and improvement of human fate in the world of organisations" (Kociatkiewicz \& Kostera, 2013, p. 13). This focus on the improvement of human life is also the core of the design thinking methodology. When pointing to the paradigmatic framework of design thinking, M. Wszołek and M. Grech write about its orientation to diagnosing problems and providing solutions effective from the user's point of view (Wszołek \& Grech, 2016, p. 12).

Therefore, the research dimension is also important here-adopting the user's point of view means refraining from pronouncing premature judgments on reality, and the focus on observation and understanding of another person. In this context, D. Sobota and P. Szewczykowski write about something like a phenomenological epoché, meaning permission for the recipient to speak on his or her own behalf and in his or her own language (Sobota \& Szewczykowski, 2014, p. 100). 
This phenomenological reduction seems to be also present in effective processes of the search for management innovation which often have to bracket old knowledge in order to open to completely different solutions.

Another characteristic which seems to combine design thinking and management innovation is the process of creative discovering by acting. Design thinking, although it intensely uses research methods, is in itself to a greater extent a method of creative problem solving through discovering innovative solutions. This way of understanding and capturing reality is also close to management which is accomplished exactly by acting, and knowledge in embedded in the specific context of its application.

Design thinking is a method of creating solutions through discovering them in constant relation to reality and its cognition. However, the cognition of reality has primarily a pragmatic dimension - it serves the creation of innovative solutions for practical problems, and new ways of thinking start with changes in the manner of operations. $\mathrm{K}$. Dorst even writes about design thinking as a new, exciting paradigm of coping with open and complex problems (Dorst, 2011, pp. 521-522), and such are the problems with which contemporary management, which requires innovations, copes poorly.

Joining the discussed before process of discovering new solutions may bring special results on the grounds of management innovation in combination with the unconventionality of thinking typical for design thinking and creating conditions for creative pushing the limits. J. Dyer, H. Gregersen and C. Christensen use in this context a vivid phrase "thinking outside the box", where the metaphorical box is to depict conventions and limitation we have to break if we want to create a real innovation (Dyer et al., 2011, p. 17). In this context, they also refer to an example of Steve Jobs who promoted and all his life believed in the maxim: "Think Different" (Dyer et al., 2011, p. 17). This, in turn, requires some courage of experimenting which, obviously, as T. and D. Kelley write, implies multiple failures. Failures which do not mean that the experiment was unsuccessful, if only constructive conclusions can be drawn from them (Kelley \& Kelley, 2015, pp. 57-59).

Therefore, prototyping proposed by design thinking seems so important in the search for management innovation. T. Brown, who together with his team used exactly design thinking to redesign the IDEO company he managed, writes about this process in the following 
way: "We redesigned IDEO because we wanted the organization to remain flexible, nimble, relevant, and responsive to the new global environment that was taking shape. Five years on, two of the original seven practices no longer exist, a new one has been added, and one has refashioned and renamed itself twice to find better resonance with its intended clients. When it comes to organizations, constant change is inevitable and everything is a prototype" (Brown, 2016, p. 123). When thinking in the categories of prototype, not only are we afraid of a failure but we are constantly open to changes, also those which are not foreseen and planned in detail, without which more radical management innovation seems impossible. Since, as T. Brown writes, "a successful prototype is not one that works flawlessly; it is one that teaches us something - about our objectives, our process, and ourselves" (Brown, 2016, p. 123).

The unconventionality of thinking discussed before seems to be closely related to creativity and innovativeness, both at the level of some desired qualities of the design thinking process participants, and the way of working. The stimulation of creativity as the essence of design thinking is pointed by, among others: D. Sobota and P. Szewczykowski (2014), D. Kelley and T. Kelley (2015), M. Wszołek and M. Grech (2016). T. Kelley and D. Kelley devoted a whole book under the symptomatic title Creative Confidence to the significance of creativity in the effective implementation of design thinking (Kelley \& Kelley, 2015). They prove in it that although most of us associate creativity with artistic jobs, it is not an innate feature. They call this wrong conviction straightforwardly "the myth of creative thinking" (Kelley \& Kelley, 2015, p. 17) and present a number of cases in which seemingly uncreative people achieved creative outcomes. M. Wszołek and M. Grech write directly: "Design thinking is also, or perhaps above all - unleashing creativity by constant prototyping of potential solutions according to the Kaizen principle: correct mistakes as soon as they are found and there is no end to improvement" (Wszołek \& Grech, 2016, p. 12).

Innovativeness is closely related to creativity. This opinion is shared by, among others, B. von Stamm, the author of a book entitled Managing Innovation, Design and Creativity (Stamm, 2008). On the one hand, innovativeness is present and extremely valued in management, on the other hand it is hard to think about design thinking in separation from innovativeness. J. Liedtka and T. Ogilvie, in their book entitled Designing for growth claim that "design thinking can do for organic 
growth and innovation what TQM did for quality" (Liedtka \& Ogilvie, 2011). Similar conclusions are presented by B. Stamm. In her opinion, if innovation is a goal, design has to be the basic component in the process of this goal implementation (Stamm, 2004, pp. 10-19). From the point of view of management innovation, it is particularly worth quoting her words: "Innovation can be and has to be in all aspects of an organization. Innovation is the art of making new connections and continuously challenging the status quo - without changing things for change's sake. Innovation is more about a certain frame of mind than a tangible product or a new technology. In an innovative organization, innovation will not be the domain of a department or a small group of people; rather, it will be everyone's responsibility, and design can be a key facilitator if it is embedded into the organization's culture" (Stamm, 2004, p. 13).

Therefore, it is necessary to build around the processes of searching for innovation an environment supporting them. T. Lockwood writes about developing cooperation and supporting interdisciplinary teams as a condition for the occurrence of real innovation, and not only incremental improvements. He points to the cooperation of designers, engineers, as well as users within one design team as a starting point for the creation of more effective innovation, better products and higher satisfaction of people (Lockwood, 2009, p. xi). In connection with the undertaken problem, a valuable remark was formulated by T. Brown when he writes about a T-shaped person made famous by McKinsey \& Company: "To operate within an interdisciplinary environment, an individual needs to have strengths in two dimensions [...]. On the vertical axis, every member of the team needs to possess a depth of skill that allows him or her to make tangible contributions to the outcome [...]. But that is not enough. Many designers who are skilled technicians, craftsmen, or researchers have struggled to survive in the messy environment required to solve today's complex problems [...]. A creative organization is constantly on the lookout for people with the capacity and - just as important - the disposition for collaboration across disciplines. In the end, this ability is what distinguishes the merely multidisciplinary team from a truly interdisciplinary one" (Brown, 2016, p. 57).

On the other hand, K. Knapp points to the quality of the work of teams. According to him, continuous improvement of the team work processes should even become an obsession to innovation-oriented 
firms. And the quality of the work of teams depends on the atmosphere of cooperation, which is able to make common work an extraordinary experience (Knapp, 2016, p. 1). With regard to management innovation, this exceptional atmosphere should become a standard not only at the level of teams, but the whole organisation. A. Preston's thought goes in this direction. He draws attention to the necessity to build the design culture in an organisation via a number of initiatives: conferences, improvement programmes, creating the joint knowledge base, and the pressure on the ethos of team work (Preston, 2004, p. 210). T. Lockwood calls these conditions the ecosystem of an organisation, claiming that conscious and systematic application of design thinking requires key changes in this ecosystem (Lockwood, 2009, pp. 23-34).

Many authors indicate the holistic view as an advantage of design thinking and its significance for innovativeness. These are, among others: B. Stamm (2004), C. Owen (2006), T. Lockwood (2009), T. Brown (2016). As C. Owen rightly says, design thinking is of a holistic character, with full understanding that problems it has to cope with are complex problems which need systemic solutions, involving equipment, procedures, policies, organisational solutions and everything that is necessary to create a comprehensive solution (Owen, 2006, p. 4).

T. Brown observes a strong relationship between the holistic approach, characteristic for design thinking, and an ability to create innovation, when he writes: "As a society our future capacity for innovation depends on having many more people literate in the holistic principles of design thinking, just as our technological prowess depends on having high levels of literacy in math and science" (Brown, 2016, p. 225). B. Stamm summarises it rightly, by showing the differences between the attitude characteristic for managers and this characteristic for designers: "Where managers tend to focus on profits and returns, designers focus on product and service quality; while managers are in for survival, designers prefer reform; where managers think linear, designers think lateral; managers are serialists, problem-oriented and cautious, designers are holistic, solutions-led, and experimental" (Stamm, 2004, p. 13).

What is important, a component of this holistic approach is also the reference to, quite commonly quoted in literature, triad of limitations marking out the area for the search for an optimum solution: the attractiveness, feasibility, and profitability of a new project (Kelley \& Kelley, 2015, p. 35; Brown, 2016, p. 50). L. Kimbell emphasises that 
one cannot reduce a solution being designed only to the aesthetic or cognitive dimension, but we must remember about the necessity to embed the process of thinking and knowledge of designers into the context in which they are working (Kimbell, 2011, pp. 295-296). A convergence with thinking in the categories of business model is revealed here. In connection with the systematic approach in the search for innovation about which, in relation to design thinking, some authors write, for example: B. Stamm (2004), J. Liedtka and T. Ogilvie (2011), or T. Brown (2016), we can talk here about systematic embedding of the solution being designed into an effective business model, which can be successfully used in the process of the search for management innovation. For T. Brown, this systematic approach means both the persistence in pursuing the goal, and linking the sought solution to the consideration of the studied opportunities and limitations arising from a broad context (organisational, social one, etc.), in which the whole process runs (Brown, 2016, pp. 167-169).

Let us summarise the deliberations undertaken in this chapter by the ascertainment of M. Gruber et al., who rightly point out that over the last two decades design thinking as a tool for creating innovation has been more and more appreciated in all types of organisations, from business to the public sector (Gruber et al., 2015, p. 1). The quoted authors write directly about the significance of design for management: "The design discipline has gone beyond product appearance and has developed in terms of industrial design, the HCI and UX design, and service and experience design to have a strategic impact on business" (Gruber et al., 2015, p. 5). The approach presents the way of thinking which is attractive from the point of view of management innovation, enabling to solve problems - complex and open ones, with which traditionally understood management still copes rather poorly.

\section{CONCLUSIONS}

The paper attempts to present design thinking as an approach which can effectively support the creation of management innovation. Innovation which, although not so rare in management practice, has not really spread in scientific literature and is often simply identified with organisational innovation, while management innovation consists of everything that significantly changes the way of the implementation 
of management functions. It is so important to contemporary organisations because by changing radically management methods they are able to sustain innovative potential in the long term. The speed of changes of the contemporary world is the reason for which permanent competitive advantage is more and more elusive.

Therefore, G. Hamel writes about the evolutionary advantage discussed in this paper as an ability to be a part of change; an ordinary reaction to changes is not enough today. The proposed design thinking approach along with the properties identified in the course of the analysis may be a potential for this advantage embedded in management innovation. To remind T. Brown's observation, in the situation of continuous change, everything in the organisation is treated as a prototype which we constantly try to improve, replace with a new one. In the beta version world, no-one is patient enough to wait for the final effect, and the directions of successive improvements cannot be predicted fully today. Once one has an idea, it is necessary to immediately build around it a team which will be able to develop it, but will be also ready to withdraw at any moment and start a completely new project, when conditionings change significantly. In such circumstances, design thinking, which we defined in the title as a source of management innovation, seems to prove itself. It is not about simple application of design thinking as a method of developing and implementing management innovation, but rather the accumulated power of influence of its aforementioned advantages in such a way that they will initiate and enable groundbreaking changes in the manner of implementing the basic management functions.

Being aware of a rather preliminary character of the problems discussed here, the scope of the paper was purposefully limited to the issues presented in this way, and the author treats them as a contribution towards further research and inquiry, also in the area of empirical research.

\section{REFERENCES}

Birkinshaw, M.M.J. (2006). How management innovation happens. MIT Sloan Management Review, 47(4), 81-88.

Braha, D., \& Reich, Y. (2003). Topological structures for modeling engineering design processes. Research in Engineering Design, 14(4), 185-199. 
British Design Council, http://www.designcouncil.org.uk/resources/search/im_field_objective/business-growth-476 (access: 20.05.2017).

Brown, T. (2008). Design thinking. Harvard Business Review, 86(6), 84-92.

Brown, T. (2016) Zmiana przez design: Jak design thinking zmienia organizacje i pobudza innowacyjność. Wrocław: Instytut Dziennikarstwa i Komunikacji Społecznej Uniwersytetu Wrocławskiego.

Dorst, K. (2011). The core of 'design thinking' and its application. Design Studies, $32(6), 521-532$.

Dyer, J., Gregersen, H. \& Christensen, C.M. (2011). The Innovator's DNA. Boston, MA: Harvard Business Review Press.

Dziadkiewicz, A. \& Maśloch, P. (2013). Design jako nowoczesny trend w zarządzaniu. Zarzadzanie i Finanse, 4(2), 93-106.

Fayol, H. (1947). Administracja przemystowa i ogólna. Poznań: Księgarnia W. Wilak.

Griffin, R.W. (2002). Podstawy zarzadzania organizacjami. Warszawa: Wydawnictwo Naukowe PWN.

Gruber, M., De Leon, N., George, G. \& Thompson, P. (2015). Managing by design. Academy of Management Journal, 58(1), 1-7.

Hamel G. (2006). The why, what, and how of management innovation. Harvard Business Review, 84(2), 72-84.

Hamel, G. Speaker. http://www.garyhamel.com/speaker (access: 19.05.2017).

Hamel, G. \& Breen, B. (2008). Zarzadzanie jutra: jakie jest twoje miejsce w przyszłości? (The Future of Management). Lublin: RedHorse.

IDEO. https://www.ideo.com/work (access: 6.05.2017).

Johansson-Sköldberg, U., Woodilla, J. \& Çetinkaya, M. (2013). Design thinking: past, present and possible futures. Creativity and Innovation Management, 22(2), 121-146.

Kelley, D. \& Kelley, T. (2015). Creative confidence. Twórcza odwaga. Warszawa: Wydawnictwo MT Biznes.

Kimbell, L. (2011). Rethinking design thinking: Part I. Design and Culture, 3(3), 285-306.

Kociatkiewicz, J. \& Kostera, M. (2013). Zarządzanie humanistyczne. Zarys programu. Problemy Zarzadzania, 11(44), 9-19.

Knapp, J. (2016). Sprint: How to Solve Big Problems and Test New Ideas in Just Five days. New York-London-Toronto-Sidney-New Dehli. Simon and Schuster.

Koźmiński, A.K. (2004). Zarzqdzanie w warunkach niepewności. Podręcznik dla zaawansowanych. Warszawa: Wydawnictwo Naukowe PWN.

Liedtka, J. \& Ogilvie, T. (2011). Designing for Growth. New York: Columbia University Press.

Lockwood, T. (2009). Design Thinking: Integrating Innovation, Customer Experience, and Brand Value. New York: Allworth Press. 
Maciag, R. (2016). W strone cywilizacji Internetu: Zarzadzanie w naukach humanistycznych. Kraków: Wydawnictwo Uniwersytetu Jagiellońskiego.

Mol, M.J. \& Birkinshaw, J. (2009). The sources of management innovation: When firms introduce new management practices. Journal of Business Research, 62(12), 1269-1280.

Owen, C.L. (2006). Design thinking: Driving innovation. The Business Process Management Institute, 1-5.

Poświata, J. (2017). Najlepsi patrzą dziś na wydajność, nie na efektywność. https:// www.hbrp.pl/b/najlepsi-patrza-dzis-na-wydajnosc-a-nie-na-efektywnosc/ hvdJfQvI (access: 16.05.2017).

Preston, A. (2004). Designing the Australian tax system. In: R.J. Boland \& F. Collopy, Managing as Designing. Stanford: Stanford Business Books, 208-213.

Sanders, E.B.N. \& Stappers, P.J. (2008). Co-creation and the new landscapes of design. Co-design, 4(1), 5-18.

Sobota, D.R. \& Szewczykowski, P. (2014). Design thinking jako metoda twórczości. Filo-Sofija, 14(27), 91-113.

Stamm, B. (2008). Managing Innovation, Design and Creativity. Hoboken: John Wiley \& Sons.

Stamm, B. (2004). Innovation - What's Design Got to Do with It? Design Management Review, 15(1), 10-19.

Wszołek, M. \& Grech, M. (2016). Komentarz do wydania II. In: T. Brown, Zmiana przez design: Jak Design Thinking zmienia organizacje i pobudza innowacyjność. Wrocław: The Institute of Journalism and Social Communication, University of Wrocław. 


\title{
DESIGN THINKING JAKO ŹRÓDKO INNOWACJI ZARZĄDZANIA
}

\begin{abstract}
Abstrakt
Tło badań. W artykule podjęto próbę przedstawienia design thinking jako podejścia, które wykorzystane w zarządzaniu może na tyle skutecznie przekształcić przyjęte w organizacji sposoby działania, że w rezultacie stanie się źródłem radykalnych zmian i innowacji samego zarządzania. Innowacje zarządzania, choć wcale nie sa takie rzadkie w praktyce zarządzania, niezbyt upowszechniły się w piśmiennictwie naukowym i często są błędnie utożsamiane z innowacjami organizacyjnymi. Składa się na nie wszystko, co istotnie zmienia sposób realizacji funkcji zarządzania. Są one bardzo ważne dla współczesnych organizacji, gdyż radykalnie zmieniając metody zarządzania, są w stanie podtrzymać potencjał innowacyjny w długim okresie.
\end{abstract}

Cel badań. Celem artykułu jest ujawnienie tych walorów podejścia design thinking, które wykorzystane we współczesnych organizacjach mogą stanowić skuteczne wsparcie w tworzeniu i wdrażaniu innowacji zarządzania.

Metodologia. Podjęte rozważania maja charakter teoretyczny i zostały oparte przede wszystkim na metodzie analizy i krytyki piśmiennictwa w zakresie design thinking oraz zarządzania, a szczególnie innowacji zarządzania. Narzędziem badawczym, które posłużyło do rozwiązania podjętego w artykule problemu naukowego, jest dedukcja, która odniesiona do krytycznego studium literatury pozwoliła osiagnaćc przyjęty cel badań.

Kluczowe wnioski. Analiza ustaleń teoretycznych doprowadziła do ustalenia, w jaki sposób podejście design thinking może skutecznie wspierać tworzenie innowacji zarządzania we współczesnych organizacjach. Design thinking, choć wywodzi się z pracy projektantów, jest obecnie podejściem do twórczego i innowacyjnego rozwiązywania otwartych, złożonych i niejednoznacznych problemów zarządzania $\mathrm{w}$ wielu organizacjach.

Słowa kluczowe: design thinking, innowacje, innowacje zarządzania, kreatywność. 